\title{
Ethical Critique of Female Characters in Pierre, Or the Ambiguities
}

\author{
Qingjuan Nie \\ Foreign Languages School \\ Qingdao Agricultural University \\ Qingdao, China \\ nieqingjuan@163.com
}

\begin{abstract}
Female ethics is one of the key ideas that Melville attempted to convey in his novel Pierre, $O$, the Ambiguities. In this study, ethical literary criticism is adopted to study the female characters in the novel. It is concluded that overbearing mother Mary carries out wrong education ethics which triggers incest between mother and son. Meanwhile, her deep-rooted traditional hierarchy ethics refrains the development of Pierre's rational ethical conscious and prohibits the construction of right ethics. Seductive and evil Isabel holds ethics of benefiting oneself at the expense of others' interests, which directly contributes to the change of ethical context, ethical identity of related characters in the novel, subsequently lead to ethical tragedy. Pure and nobleminded Lucy undergoes the growth in love and marriage ethics and ultimately becomes a model of female ethics. Melville made a profound study of these female characters and conducted a moral critique of female ethics by means of vividly portraying the ethical consciousness and moral behaviors of these abovementioned three female characters and further expressed his ethical ideals and ethical concern as well.
\end{abstract}

Keywords-Melville; Pierre; Feminine Ethics; Ethical Critique

\section{INTRODUCTION}

Feminine ethics is a study of the specific situations and corresponding moral problems that would often come to rise in the whole process of women's life. It can both refer to a special contradiction that women face as the inferior gender and also indicate a special moral requirement raised by society to women [1]. Unlike male ethics, feminine ethics highlights ethical concerns of family, marriage and love by household women. In the domestic novel Pierre, Or the Ambiguities, Melville constructed several totally different female characters, such as arrogant mother Mary, seductive and evil half sister Isabel and pure and noble-minded fiancée Lucy. Based on ethical literary criticism, through analyzing the ethics and behaviors of these female characters in the novel, this paper is an attempt to reveal the hidden reasons, arguing that as Melville conducted moral critique of these female characters, he also expressed his ethical ideals and ethical concern as well.

This work is financially sponsored by Research Project of Humanities and Social Sciences in Universities of Shandong Province, China (J16YC12), National Foreign Languages Teaching and Research Program, China (2015SD0022B), Key Project of Art and Science in Shandong, China (201706502), Research Project of Humanities and Social Sciences in Qingdao Agricultural University, China (614Y33).

\section{ARROGANT MOTHER---MARY}

Newton Arvin argues that the romantic relationship between Pierre and his mother has changed the daily communication into doubtful sexual relation [2]. As a matter of fact, readers can easily find the similarities between Pierre's mother and Melville's mother if they can read carefully. In Pierre, Mary had a noble origin, with inherent vanity, nobility and beauty. However, her husband died early, so the solitary Mary dumped all her love onto the only son Pierre. At the same time, Pierre also tried to seek all parental love he needed from his mother. Therefore, deformity arose and mother-son relation gradually evolved into sexual love.

Newton Arvin argues that the romantic relationship between Pierre and his mother has almost changed the daily communication into doubtful sexual relation [2]. As a matter of fact, readers can easily find the similarities between Pierre's mother and Melville's. In Pierre, Mary has a noble origin, with inherent vanity, nobility and beauty. However, her husband died early, so the solitary Mary dumped all the love onto her son Pierre while Pierre also tried to seek parental love from his mother. Therefore, mother-son relation gradually deformed and evolved into sexual love.

The incestuous relationship between Mary and her son Pierre is skillfully presented by the narrator. In this novel, Mary felt discontent with all men except her son. It is selfevident that Mary had already perceived her son as the ideal lover or husband. On the other hand, Pierre swore more than once that any man whether he had beard or not would disappear immediately from the world if he dared to propose to his mother. Based on the description of these abnormal relation, it can be concluded that the blood relationship between mother and son has transformed into the love of the sexes, consequently incest between mother and child incest arises. In the context of literary writing, "incest" is usually represented in two forms, namely, incest desire or will at the spiritual level and incest behavior at the physical level [3]. In Melville's Pierre, the incest is only confined to spiritual realm, that is desire or cue for incest rather than actual incestuous behavior or sexual contact. Whatever it is, mother and child incest seriously violates ethical taboo built on blood relationship for thousands of years. According to professor Zhenzhao Nie, ethical taboo is derives from the rational development of 
human. Before becoming a person of reason, instinct and desire driven by instinct are fully respected and grow at its will [4]. Similarly, if the blood relationship between mother and child is allowed to develop so randomly as to free from reason, it will rise above reason and evolve into love between two sexes. Thus, ethical taboo is violated and incest happens.

Who is to blame for the incest? It is more than natural for Pierre as a boy to seek all parental love he needed from his mother since his father died early, let alone a child whose right ethical consciousness and moral values hadn't been completely established. In contrast, Mary had noble origin who received good education. She is supposed to know quite well that mother and son incest is shockingly serious immoral behavior. Meanwhile, she should realize the role that mother plays in children rearing morally as a role model. It is a pity that rather than served as a role model, Mary referred to her son as brother. Such a frivolous act is clearly contrary to the traditional ethics. Moreover, the cue for sex caused by Mary's too much importance to appearance, her provocative language and ambiguous acts conveyed a wrong message of sexual relation, which seriously distorted Pierre's ethical concept, strengthened Pierre's impulse for sex or sexual contact rather than affection for his mother. All of the above combined to promote the motherly love to mother and son incest.

Melville's intentionally negative portrait of Mary to some extent may be influenced by his own mother Mary. As a young widowed mother, Mary favored her eldest son Gansevoort, a clever, handsome and capable man whom the mother could rely on both mentally and financially. Unfortunately, Gansevoort died young, which was undoubtedly a huge blow to the mother. In contrast, Herman Melville, the second son of Melville family is ineloquent, plain, hard to be appreciated by his mother. Melville once said to his niece about his mother's hatred of himself. We have good reason to assume that the mother Mary shifted her grief caused by the sudden death of her favorite boy Gansevoort to her second son Melville, thus contributed to the gap between Melville and his mother. Unable to get the same love as his brother Gansevoort did from their mother, Melville felt hated, leading to the negative reconstruction of the widowed mother Mary in the novel.

\section{SEDUCTIVE AND EVIL ISABEL}

The Gothic tradition flourished in American romantic writings in the middle of the nineteenth century. Writers revealed the diseases and ailments of religious society and dark side of human nature and represented rational and profound social introspection and moral exploration inside the irrational texts with the help of "black" tradition of Gothic novels [5]. Pierre, Or the Ambiguities is one book embedded with the strongest taint of Gothic tradition among all Melville's works, filled with supernatural Gothic elements like darkness, horror, mystery with the mysterious illegitimate Isabel as the central embodiment.

Isabel was the illegitimate daughter of Pierre's father. She lived a solitary and hard life. Isabel was totally mysterious. However, she was unusually beautiful. Her dark skin showed great vitality, and her sweet voice had such an enchanting power like magic that could easily attract Pierre to her. In this novel, in order to alleviate the miserable life and get out of trouble, Isabel decided to write to Pierre to reveal her own identity. "---Oh, my brother, my dear, dear Pierre, ---help me, fly to me; see, I perish without thee; ---pity, pity,---here I freeze in the wide, wide world; ---no father, no mother, no sister, no brother, no living thing in the fair form of humanity, that holds me dear. ..... Fly to me, Pierre". This ethical act becomes one of the core events to promote the development of the story influenced by which Pierre was forced to make ethical choices. In fact, no matter what choice Pierre made, the results would not be harmful to Isabel. If considered from the perspectives of purpose, means and moral principles of ethical acts, Isabel's behavior could be clearly defined as the one benefiting oneself at the expense of others. In other words, this ethical behavior aims to achieve one's own purpose by means of harming others [6]. Melville expressed his criticism of this type of women from an omniscient narrative perspective, "If Pierre can read the letter anew, maybe he will soon be able to find the intense expectation lurked in Isabel. How can such an honest girl like Isabel be so selfish to be willing to spoil other's marriage?" It can be seen that Melville pushed Isabel onto the moral trial because achieving one's own happiness at the expense of other's lifetime wellbeing goes against the uttermost moral principle and also could be regarded as the harshest evil. It violated the most basic moral principle altruism. Therefore, such immoral behavior should be severely criticized and condemned.

The immoral ethical desire that Isabel revealed was rather contemptible and the means to achieve this desire should be equally condemned. The narrator repeatedly mentioned how Melville was tempted by Isabel's soft, sweet, wild, and slightly exotic voice. It sounds like both Siren who often attracted the past seamen with her magic sweet songs and the evil Satan who seduced Adam and Eve to eat the forbidden fruit on the tree in the central park of Garden of Eden. In addition, the image of guitar strengthened Isabel's evil. Playing the guitar as Isabel is singing, she looked like a witch, trying to cast magic over Pierre. "Pierre was bound in the garden of witch like a visitor, motionless". The use of Gothic elements and symbols of mystery and evil to a large extent reflected the dark ethical means of Isabel, which was created by Melville to express his criticism of the type of woman characterized by darkness and seductiveness, represented by Isabel. They make the most of their female temperament like unusual beauty and sweet voice to tempt men and soften their ethical consciousness until throw them into irrational situation and ultimately lead them to commit serious ethical sin.

\section{PURE AND NOBLE-MINDED LUCY}

As Melville criticized the two types of women represented by arrogant Mary and seductive Isabel, he also affirmed the pure and noble-minded type represented by Lucy. In the novel, Melville portrayed Pierre's fiancé Lucy as an ethical model who was both pure and noble-minded and who was the incarnation of beauty and good. By juxtaposing these different types of women, Melville attempted to demonstrate his ethical idea over women.

Lucy was Pierre's fiancée. She not only had good looks but also had noble mind and an obsessed faith in love. Even though 
she learned that her fiancé Pierre fled away with another girl, she still persisted in loving Pierre and even felt ready to be the servant at the cost of fame and high social status. In her letter, she claimed, "oh, my heavenly Pierre, shall henceforth be one mute wooing of each other, with no declaration, no bridal, till we meet in the pure realms of God's final blessedness for us; --till we meet where the ever-interrupting and ever-marring world cannot and shall not come. ......I hold faith to love. So I think this is true love". Lucy's noble promise truly revealed her love ethics based on tolerance and mutual understanding free from the fetter of earthly things. In this book, Melville attributed Lucy's motivation for love to Gothic mysterious power. "Pierre's self sacrifice and kindness to help others make Pierre as noble as an angel and transfers the noble quality and power to Lucy". Lucy also wrote in her letter that it was God who guided her here. Completely different from Isabel who held the belief of "egoism", Lucy carried on the ethical thought of "altruism", and grounded love ethics on such belief. She realized that love was not completely possessive but love of the soul, mutual understanding, mutual support, willingness to do anything for each other, even sacrificing one's own life.

Self sacrifice is the noble act by the doer who is willing to give up the legitimate interests of the individual for the sake of interests of others and the society as well [7]. Like Pierre, Lucy was also a fine model of self sacrifice. She had not only realized her own moral value but also established noble love ethics at the expense of fame, wealth and social status, thus growing up to be a goddess-like person. "As if her body indeed were the temple of God, and marble indeed were the only fit material for so holy a shrine, a brilliant, supernatural whiteness now gleamed in her cheek. Her head sat on her shoulders as a chiseled statue's head, and the soft, firm light in her eye seemed as much a prodigy, as though a chiseled statue should give token of vision and intelligence". Currently, Lucy had taken on the splendor of divinity after the secular element gradually faded away. Melville expressed his recognition and praise of such kind of role model of morality represented by Lucy by using words with "divine nature" like "sacred", "worship". Love, caring for others and sacrifice are the most important elements in female ethics. Lucy, who was willing to sacrifice herself, was undoubtedly the ethical model of society at that time. The reason Melville intended to portray Lucy as the ideal female may be largely attributed to Melville's hesitation to challenge readers' moral standard and his eagerness to get free from financial worry and win back the audience who had departed from Melville due to the incomprehensible Moby Dick and regain his writing success since his new book Moby Dick annoyed the large audience.

\section{CONCLUSION}

Melville once said in a letter to Mrs. Hawthorne Sofia, "the goddess of fate forced me down into some kinds of stupid contemplation. I decide that the next book will be a dessert for women." [8] As the uncanny Moby Dick really scared away many readers after its first publication, Melville shifted his attention on his target readers to females who were more interested in such domestic topics like love, marriage and household life. In Pierre, Melville focused on feminine ethics. By shaping several women in the novel and analyzing their ethical consciousness and ethical choice and behavior in different contexts, Melville attempted to give his ethical judgment. Melville's advocating feminine ethics based on love and sacrifice not only meets the requirement for ethics and morality of that time but also fulfills the expectation of female readers. In fact, Melville had already noticed the description of family values and ethical relationship in popular fiction [9] when he was writing Moby Dick. However, due to his lack of writing experience in popular fiction and parody allusions and artificial language, Pierre finally ended up in a "violent" book of misfortune. Anyway, Melville's critique of female characters in Pierre and his profound exploration of family and marriage ethics make this book a great book of morality [2].

\section{REFERENCES}

[1] Tang Lin, A study on feminie ethics in song dynasty. Hefei University, 2011. (In Chinese)

[2] N. Arvin, Herman Melville. New York: The Viking Press, 1963, pp. 219-222.

[3] J. J. Yang, "Motif of incest and narrative literature in China and abroad," in Foreign Literature Review, No. 4, Beijing: 2000, pp. 59-68. (In Chinese)

[4] Z. Z. Nie, "Ethical literary criticis: fudamental theory and items," in Foreign Literature Study, No. 1, Wuhan: 2010, pp. 12-22. (In Chinese)

[5] T. T. Liu, On inheritance and transcendence of Gothic novles in Hawthorne's works. Nanjing Normal University, 2008. (In Chinese)

[6] H. M. Wang, "On principles of good and evil," in Journal of Yuxi Teachers College, No. 5, Yuxi: 2004, pp. 1-6. (In Chinese)

[7] C. L. Wei, "A study on essence and quantity of self-sacrifice," in Journal of Henan Normal University, No. 5, Zhengzhou: 1993, pp. 19-23. (In Chinese)

[8] A. Delbanco, His World and Work. London: Pan Macmillan Ltd, 2006.

[9] J. C. Yang, "On writing intention and narrative structure of Pierre, Or the Ambiguities," in Foreign Literature Review, No. 4, Beijing: 2005, pp. 99-106. (In Chinese) 